Int. J. Morphol.,

36(1):145-148, 2018

\title{
Variations of the External and Internal Jugular Veins: A Fetal Study
}

\author{
Variaciones de las Venas Yugulares Externas e Internas: Estudio Fetal
}

P. Pillay ${ }^{1}$; S. Ishwarkumar ${ }^{1}$ \& K. S. Satyapal ${ }^{1}$

PILLAY, P.; ISHWARKUMAR, S. \& SATYAPAL, K. S. Variations of the external and internal jugular veins: A fetal study. Int. J. Morphol., 36(1):145-148, 2018.

SUMMARY: The external jugular vein (EJV) is formed by the union of the posterior division of the retromandibular vein and posterior auricular vein, while the internal jugular vein (IJV) is a continuation of the sigmoid sinus. A number of variations in the formation, lengths and drainage patterns of EJV and IJV have been documented in adults, however there is a paucity of literature regarding fetal studies. This study aimed to highlight variation patterns of external and internal jugular veins in 40 fetuses ( $\mathrm{n}=80$ ). This study included the bilaterally dissection of the neck region in 40 fetuses between the gestational ages of 15-28 weeks at the University of KwaZulu-Natal as per Grants Dissector. This study observed three variations in the pattern of the EJV and IJV. With regard to the EJV, duplication occurred on the sternocleidomastoid muscle in $4 \%$ of the specimens sampled in this study, which concurred to a study conducted by Olabu et al. (2015) in a Kenyan sample. The "Y-shaped" IJV occurred in $1 \%$ of the specimens, however the "Y-shaped" IJV gave off a tributary to the EJV in $3 \%$ of the specimens sampled in this study. Lalwani et al. (2006) stated a rare venous communication between the EJV and IJV. The knowledge of the variable patterns of the external and internal jugular veins are important to clinicians performing micro-vascular surgeries in head and neck region.

KEY WORDS: External jugular vein; Internal jugular vein; Anatomical variation; Fetal.

\section{INTRODUCTION}

According to standard anatomical textbooks, the external jugular vein (EJV) is chiefly responsible for draining the scalp and face and is formed by the union of the posterior division of the retromandibular vein and posterior auricular vein near mandibular angle (Standring et al., 2012; Sinnatamby, 2011). It then descends diagonally, superficial to the sternocleidomastoid muscle to reach the subclavian vein (Standring et al.). The internal jugular vein (IJV) begins from the posterior compartment of the jugular foramen and is a continuation of the sigmoid sinus (Standring et al.; Sinnatamby). It is located within the carotid sheath with the common carotid artery and the vagus nerve and unites with the subclavian vein to form the brachiocephalic vein (Standring et al.; Sinnatamby). In addition, variations in the formation, lengths and drainage patterns of EJV and IJV has been documented in adults (Choudhry et al., 1997; Nayak, 2006; Downie et al., 2007), however reports of fetal studies are minimal. Alaani et al. (2005) stated that unilateral duplication of the IJV is rare. Downie et al. classified the variations of IJV into two patterns: duplicate and fenestrated. They further described that duplication which was limited to those cases where the branches of IJV remain separate over the entire course, while fenestration should be used for the case in which the branched vessel reunites into a single "normal" vessel. In 1937, Pikkieft reported duplication of EJV in $5.3 \%$ of their dissections, while Olabu et al. found that $2.2 \%$ of their sample had a duplicate EJV.

Furthermore, the IJV is of clinical importance to clinicians as inspection, auscultation and Dopplerultrasonic examinations of these veins provide evidence that may aid in the diagnosis of cardiac diseases (Balachandra et al., 2012). Consequently, dilatation of the jugular veins may be a result of compression of the superior vena cava, which indicates potential pathologies within the mediastinum or pericardial sac (Balachandra et al.). Therefore, knowledge regarding variation pattern of the

\footnotetext{
${ }^{1}$ Department of Clinical Anatomy, School of Laboratory Medicine and Medical Sciences College of Health Sciences, University of KwaZulu-Natal Westville Campus Private Bag X54001, Durban 4000, South Africa.
} 
external and internal jugular veins are important to clinicians performing vascular surgeries in head and neck region, as well as those performing angioplasty, catheterization and occasionally hemodialysis (Sankar \& Bhanu, 2011; Balachandra et al.). Therefore this study aims to highlight variation patterns of external and internal jugular veins, which were observed during the gross anatomical micro-dissection of the anterior and posterior triangles of the neck in 40 fetuses $(n=80)$.

\section{MATERIAL AND METHODS}

General: This study conducted a bilaterally dissection of 40 fetuses between the gestational ages of 15-28 weeks. The fetal specimens were obtained from Clinical Anatomy, School of Laboratory Medicine and Medical Science at the University of KwaZulu-Natal (Westville and Nelson Mandela School of Medicine campuses). Ethical clearance was obtained (BF: 156/07) and complied with the regulations of the National Health Act 61 of 2003.

Methodology: The sternocleidomastoid muscle was removed from its attachment to the clavicle and mastoid process. The lesser occipital, great auricular, transverse cervical and supraclavicular nerves were preserved. The fascia covering the floor of the posterior triangle was removed by fine dissection and the scalene muscles, levator scapulae muscle and splenius capitus muscle were exposed and identified. The common carotid artery, vagus nerve and internal jugular vein were dissected to expose its relationship to the ansa cervicalis. The dissections were recorded using a Canon digital Powershot G5 camera (4x optical zoom).



Fig. 1. Duplication of the external jugular vein ("H" shaped).

\section{RESULTS}

Variations of the External Jugular Vein. Duplication of EJV. In 3/80 (4\%) of the fetal specimens, a duplicated EJV (with an " $H$ " shaped communication joining the two), was located on the sternocleidomastoid muscle (SCM). The transverse cervical vein (TCV) drained into one part of the EJV. The transverse cervical nerve (TCN) intertwined with EJV (Fig. 1).

Variations of the Internal Jugular Vein. " $Y$ "- shaped IJV. In $1 / 80(1 \%)$ of the fetal specimens, the internal jugular vein had a "Y" shaped appearance. The upper part of the superior root of the ansa cervicalis was located at the junction of the "Y" (indicated by arrow) and a lower part was located medial to the internal jugular vein (Fig. 2).

"Y"-shaped IJV with a tributary from EJV. In 2/80 ( $3 \%)$ of the fetal specimens, the internal jugular vein divided into two and received a tributary from the external jugular vein superiorly and inferiorly. Furthermore, the ansa cervicalis looped around the lower end of the internal jugular vein (Fig. 3).

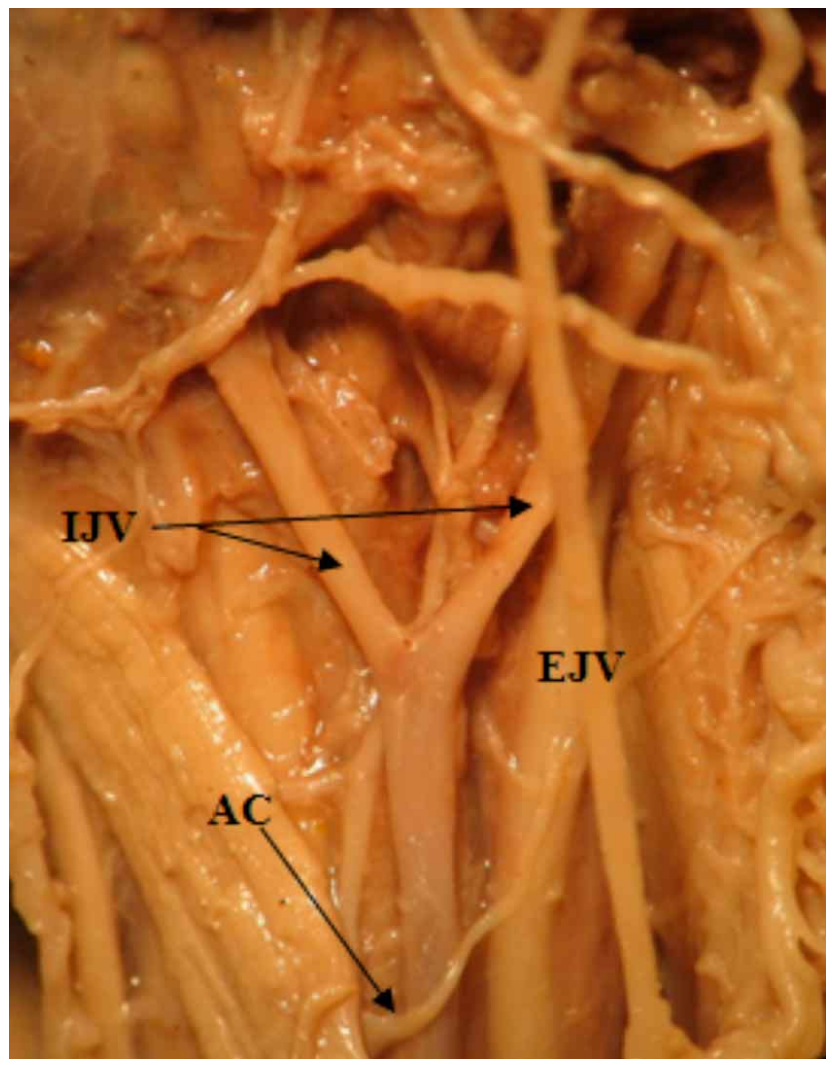

Fig. 2. "Y" shaped internal jugular vein. 




Fig. 3. "Y" shaped internal jugular vein with a tributary from external jugular vein .

\section{DISCUSSION}

The knowledge of anatomical variations of the jugular veins is significant for any venous ligations conducted during surgical procedures, such as radical neck dissections (Balachandra et al.).

The EJV has been reported to show a number of variations that may affect its tributaries, size, drainage, form, course and termination (Pikkieft; Salmeri et al., 1991; Choudhry et al.; Yadav et al., 2000; Singla et al., 2011). The duplication of the EJV occurred in $4 \%$ of the specimens in this study, furthermore the transverse cervical vein drained into one part of the EJV, while the transverse cervical nerve intertwined with the EJV. In an earlier study conducted by Pikkieft, it was found that the EJV was duplicated in $5.3 \%$ of their sample. Furthermore, Olabu et al. reported that in $2.2 \%$ of their Kenyan sample, the EJV was duplicated. However, Choudhry et al. reported that the EJV split into two parts on the external surface of the SCM muscle but re-joined at the junction of the facial vein.
The internal jugular vein is the largest vein of the head and neck and it is a continuation of the sigmoid sinus which drains the intracranial and deep structures of the head and neck region (Standring et al.; Deepak et al., 2015). However, in this study, the internal jugular vein divided into two and received a tributary from the external jugular vein in $3 \%$ of the sample. Similarly, Lalwani et al. recorded a rare venous communication between the EJV of one side, which drained into the IJV on the opposite side. In addition, Olabu et al. recorded that EJV terminated into IJV in $7.7 \%$ of the cases studied.

In $1 \%$ of the fetal specimens in this study, the internal jugular vein had a "Y" shaped appearance. Biondi et al. (2009) recorded that the right jugular vein bifurcated about $2 \mathrm{~cm}$ from the jugular foramen and drained into the right subclavian vein (Deepak et al.).

Rossi \& Tortori-Donati (2001) postulated that the duplication of vessels may occur in the third and the sixth week of the gestational development as a result of developmental derangement (Snoj \& Cvetko, 2013). Furthermore, it has been stated that IJV duplication is frequently recorded to be associated with phlebectasia, which suggests abnormalities in the development of the venous wall, perhaps involving incomplete development of the muscular layer (Som et al., 1985; Rossi \& Tortori-Donati; Turan-Ozdemir et al., 2004; Snoj \& Cvetko). Dodo (1986) suggested that the jugular foramen has a bony partition that may be caused by an intra-jugular process of occipital bone, this partition may result in duplication of IJV (Sankar \& Bhanu).

\section{CONCLUSION}

This study observed three variations in the pattern of the EJV and IJV. With regard to the EJV, duplication occurred in $4 \%$ of the specimens. The "Y-shaped" IJV occurred in $1 \%$ of the specimens; however the "Y-shaped" IJV gave off a tributary to the EJV in $3 \%$ of the specimens sampled. Knowledge of these variable patterns of the external and internal jugular veins is of clinical import.

PILLAY, P.; ISHWARKUMAR, S. \& SATYAPAL, K. S. Variaciones de las venas yugulares externas e internas: Estudio fetal. Int. J. Morphol., 36(1):145-148, 2018.

RESUMEN: La vena yugular externa (VYE) está formada por la unión de la división posterior de la vena retromandibular y la vena auricular posterior, mientras que la vena yugular interna (VYI) es una continuación del seno sigmoideo. En adultos se han 
documentado una serie de variaciones en la formación, las longitudes y los patrones de drenaje de la VYE y la VYI, sin embargo hay escasa literatura con respecto a estudios fetales. Este estudio tuvo como objetivo destacar los patrones de variación de las venas yugulares externa e interna en 40 fetos $(\mathrm{n}=80)$. El estudio incluyó la disección bilateral de la región del cuello en 40 fetos de edades gestacionales entre 15-28 semanas en la Universidad de KwaZuluNatal. Se observó tres variaciones en el patrón de la VYE y la VYI. Con respecto a la VYE, se produjo duplicación en el músculo esternocleidomastoideo en el $4 \%$ de los especímenes, lo que coincidió con un estudio realizado por Olabu et al. en una muestra keniana. La VYI en "Y" se observó en el $1 \%$ de los especímenes, y otorgó un afluente a la VYE en el $3 \%$ de los especímenes muestreados en este estudio. Lalwani et al. describió una rara comunicación venosa entre la VYE y la VYI. El conocimiento de los patrones variables de las venas yugulares externa e interna es importante para los médicos que realizan cirugías microvasculares en la región de cabeza y cuello.

PALABRAS CLAVE: Vena yugular externa; Vena yugular interna; Vena; Variación anatómica; Fetal.

\section{REFERENCES}

Alaani, A.; Webster, K. \& Pracy, J. P. Duplication of internal jugular vein and relation to the spinal accessory nerve. Br. J. Oral Maxillofac. Surg., 43(6):528-31, 2005.

Balachandra, N.; Padmalatha, K.; Prakash, B. S. \& Ramesh, B. R. Variation of the veins of the head and neck - external jugular vein and facial vein. Int. J. Anat. Var., 5:99-101, 2012.

Biondi, P.; Colella, G.; Gherardini, G.; Tartaro, G. \& Rauso, R. Internal jugular vein duplication. Indian J. Plast. Surg., 42(2):273-4, 2009.

Choudhry, R.; Tuli, A. \& Choudhry, S. Facial vein terminating in the external jugular vein. Surg. Radiol. Anat., 19(2):73-7, 1997.

Deepak, C. A.; Sarvadnya, J. J. \& Sabitha, K. S. Variant anatomy of internal jugular vein branching. Ann. Maxillofac. Surg., 5(2):284-6, 2015.

Dodo, Y. Observations on the bony bridging of the jugular foramen in man. J. Anat., 144:153-65, 1986.

Downie, S. A.; Schalop, L.; Mazurek, J. N.; Savitch, G.; Lelonek, G. J. \& Olson, T. R. Bilateral duplicated internal jugular veins: case study and literature review. Clin. Anat., 20(3):260-6, 2007.

Lalwani, R.; Rana, K. K.; Das, S. \& Khan, R. Q. Communication of the external and internal jugular veins: a case report. Int. J. Morphol., 24(4):721-2, 2006.

Nayak, B. S. Surgically important variations of the jugular veins. Clin. Anat., 19(6):544-6, 2006.

Olabu, B. O.; Loyal, P. K.; Matiko, B. W.; Nderitu, J. M.; Misiani, M. K. \& Ogeng'o, J. A. Variant anatomy of the external jugular vein. Anat. J. Afr., 4(1):518-27, 2015.

Pikkieft, E. Subcutaneous veins of the neck. J. Anat., 72(Pt. 1):119-27, 1937.

Rossi, A. \& Tortori-Donati, P. Internal jugular vein phlebectasia and duplication: case report with magnetic resonance angiography features. Pediatr. Radiol., 31(2):134, 2001.

Salmeri, K. R.; Bellah, J. R.; Ackerman, N. \& Homer, B. Unilateral congenital aneurysm of the jugular, linguofacial, and maxillary veins in a dog. J. Am. Vet. Med. Assoc., 198(4):651-4, 1991.

Sankar, K. D. \& Bhanu, P. S. Variant anatomy of fenestrated internal jugular vein with unusual retromandibular and facial vein. Int. J. Anat. Var., 4: 144-8, 2011.
Singla, R.K., Singla, S., Sachdeva, K. Partial duplication of external jugular vein forming a venous ring around supraclavicular nerve: A case report. J. Clin. Diagn. Res., 5(4):859-61, 2011.

Sinnatamby, C. S. Last's Anatomy. Regional and Applied. $12^{\text {th }}$ ed. New York, Churchill Livingstone/Elsevier, 2011.

Snoj, Z. \& Cvetko, E. A case of unilateral fenestration and duplication of the external jugular vein. Int. J. Morphol., 31(1):107-9, 2013.

Som, P. M.; Shugar, J. M.; Sacher, M. \& Lanzieri, C. F. Internal jugular vein phlebectasia and duplication: CT features. J. Comput. Assist. Tomogr., 9(2):390-2, 1985.

Standring, S. Gray's Anatomy: The Anatomical Basis of Clinical Practice. $40^{\text {th }}$ ed. Philadelphia, Elsevier, 2012.

Turan-Ozdemir, S.; Coskun, H. \& Balban, M. Phlebectasia of the external jugular vein associated with duplication of the internal jugular vein. Clin. Anat., 17(6):522-5, 2004.

Yadav, S.; Ghosh, S. K. \& Anand, C. Variations of the superficial veins of the head and neck. J. Anat. Soc. Ind., 49(1):61-2, 2000.

Email: satyapalk@ukzn.ac.za

Received: 27-02-2017

Accepted: 11-09-2017 